УДК: 338.1: 658.78

МАГОМЕДОВ АЛИ МАГОМЕДОВИЧ

к.э.н., профессор кафедры «Прикладная информатика и математические методы в управлении», ФГБОУ ВО «Дагестанский государственный университет», e-mail: ali1955@mail.ru

МАГОМЕДОВА МАДИНА МАЛИКОВНА

д.э.н., профессор, заведующая кафедрой «Национальная и региональная экономика», проректо ФГБОУ ВО «Дагестанский государственный университет», e-mail: magomedova-mm@mail.ru

\title{
ЛОГИСТИЧЕСКАЯ ИНТЕГРАЦИЯ И СТРУКТУРНАЯ СБАЛАНСИРОВАННОСТЬ АПК РЕГИОНА
}

\begin{abstract}
Аннотауия. Введение. B статье рассматриваются вопросы использования логистиче-

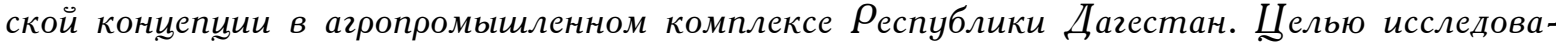
ния является анализ АПК региона с позищий логистической концепиии, выявление причин несбалансированности структуры АПК региона и выработка предложений по развитию звеньев хранения и переработки сельскохозяйственного сырья в продуктовой логистической иепи. Методы исследования. Применяемая в работе логистическая парадигма основывается на логике суждений по синтезу и анализу логистических систем и иепей в агропромышленном комплексе региона. При исследовании объекта основополагающим методологическим подходом выступает системный подход как общенаучная методология. Результаты. Агропромышленный комплекс - эта открытая сложная социо-экологоэкономическая система, состоящая из множества подсистем, которые могут высту пать как отдельные элементы логистической системы. Разнородные потоковые проиессы в АПК (природно-ресурсные, материальные, финансовые, институичональные, информационные и трудовые) должны количественно и качественно соответствовать задачам логистической оптимизации. Аграрный сектор является системообразуюшим для всей экономики республики, однако его потенииал не используется в полном объеме. При этом главной причиной отставания в развитии АПК является ее структурная несбалансированность. Область применения. Определены особенности и проблемы интегрирования перерабатывающей отрасли в АПК республики. Рекомендаиии авторов могут быть учтены при разработке иелевых региональных программ развития АПК и перерабатывающей промышленности. Выводы. Применение логистической кониепиии направлено на оптимальное использование природно-ресурсной среды региона, производственного потенциала отраслей агропромышленного комплекса, преодоление диспропориий и устранение несбалансированности на пути сельскохозяйственной продукиии от производителя к конечному потребителю, повышение сохранности продукиии и комплексную ее переработку на основе современных технологий, ускорение развития тех подсистем, отставание которых тормозит развитие всей системы.
\end{abstract}

Ключевые слова: агропромышленный комплекс, логистическая интеграция, кооперация, господдержка.

MAGOMEDOV ALI MAGOMEDOVICH

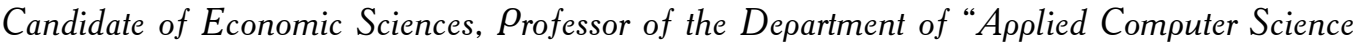
and Mathematical Methods in Administration", FSEBI of HE "Dagestan State University", e-mail:ali1955@mail.ru

MAGOMEDOVA MADINA MALIKOVNA

Doctor of Economic Sciences, Professor, Head of the Department of "National and Regional Economics", Vice-Principal of FSEBI of HE "Dagestan State University", e-mail:magomedova-mm@mail.ru 


\title{
LOGISTIC INTEGRATION AND STRUCTURAL BALANCE OF THE AIC OF THE REGION
}

\begin{abstract}
Introduction. The manuscript discusses the issues of using the logistic concept in the agro-industrial complex of the Republic of Dagestan. The goal of the study is an analysis of the AIC of the region from the points of view of the logistic concept, finding reasons of imbalance of the structure of the AIC of the region, and developing suggestions about the development of the elements of storing and processing of agricultural raw materials in the product logistic chain. The methods of research. The logistic paradigm used in the study is based on the logic of reasoning on the synthesis and analysis of logistic systems and chains in the agro-industrial complex of the region. When studying the subject, the prevailing methodological approach is the systemic approach as the general scientific methodology. The results. The agro-industrial complex is an open complex socio-environmental-economic system consisting of a variety of subsystems that may serve as separate elements of a logistic system. The multifold stream processes in the AIC (natural resource based, economic, financial, institutional, information and labor) have to qualitatively and quantitatively correspond to the tasks of logistic optimization. The agrarian sector is system-forming for the whole economy of the republic, however, its potential is not fully utilized. With that, the main reason for the delay in the development of the AIC is its structural imbalance. The area of application. We have determined the typical features and the problems of integration of the processing industry in the AIC of the Republic. The recommendations of the authors may be taken into account when developing targeted regional programs of development of the AIC and the processing industry. The conclusions. The use of a logistic concept is directed towards an optimal usage of the natural and resource environment of the region, the production potential of industries of the agro-industrial complex, overcoming disproportions and eliminating the imbalance on the road of agricultural products from the producer to the final consumer, improving the shelf life of products and its complex processing based on modern technologies, accelerating the development of those subsystems the delay in the development of which slows down the development of the whole system.
\end{abstract}

Keywords: the agro-industrial complex, the logistic integration, cooperation, state support

Введение. Агропромышленный комплекс выступает как один из элементов общей национальной экономической системы, является одновременно сложной и открытой природносоциально-экономической системой, состоящей из различных подсистем. В составе агропромышленного комплекса выделяют различные подсистемы, к числу основных следует отнести: природно-ресурсная подсистема; аграрное производство; материально-техническое обеспечение сельского хозяйства; заготовка, хранение, переработка сельскохозяйственной продукции; а также отрасли производственной, рыночной и социальной инфраструктуры.

Каждая подсистема, являясь элементом более крупной системы, в свою очередь выступает как отдельная система по отношению к составляющим ее элементов.

Как известно, в логистике основополагающим принципом является системный подход. Относительно АПК также требуется применить именно системный подход, так как он включает в себя взаимосвязанные и взаимообусловленные виды деятельности. Интегративная концепция логистики нашла широкое применение в промышленности и бизнесе. Однако даже в развитых странах, где логистика развита в полную мощь, логистика в аграрной сфере только начинает осваиваться [22].

Использованию логистики в агропромышленном комплексе посвящено немало публикаций. Но многие авторы при этом подразумевают под логистикой материально-техническое снабжение сельского хозяйства, транспортировку продукции и ее складирование, выхолащивая тем самым суть интегрированного логистического подхода. В публикациях такого рода имеется превалирование функциональной парадигмы логистики над интегративной парадигмой. Запасы и транспортировка - вот основные функциональные области, которые находятся в фокусе современных исследований по логистике АПК $[15,20]$. Во многом это объясняется тем, что суммарные потери в развивающихся странах в этих областях колеблются от 20-50 \%.

Отдельные авторы, пытаясь применить интегративный, системный подход в АПК, копиру- 
ют схемы логистизации с других отраслей экономики без учета особенностей самого объекта исследования. Такого рода публикации по логистике в АПК отличаются от общей литературы по логистике лишь отдельными примерами [4]. Обычное переименование системы АПК в логистическую ничего не дает.

Позиция авторов в данном вопросе отличается принципиально и обусловлена потребностью в исследовании объекта как макрологистической системы на основе интегративной концепции.

Методы исследования. В ходе исследования использованы междисциплинарный и экономико-статистический виды анализа, выявлены региональные особенности развития интеграционных связей между производством и переработкой сельскохозяйственной продукции, а также причинно-следственные связи в исследуемых объектах. Использование логистической парадигмы основывается на логике суждений по синтезу и анализу логистических систем и цепей в агропромышленном комплексе региона. При исследовании объекта основополагающим методологическим подходом выступает системный подход как общенаучная методология.

Авторы при этом основываются на выдвинутых ими гипотезах, которые нашли отражение в научных публикациях. В частности, было предложено применить логистическую концепцию в природопользовании и землепользовании [12], а также выделить институциональные потоки как существенный элемент потокового процесса в логистических системах [11].

Результаты. Агропромышленный комплекс в экономике Республики Дагестан играет решающую роль. Доля сельскохозяйственного производства в валовой добавленной стоимости составляет $15,5 \%$, в то время как по стране этот показатель равен 5,2 \%. Это говорит об аграрной специализации республики. Однако потенциал АПК республики, по оценкам специалистов, используется лишь на $15-20 \%$ [9].

Главной причиной сдерживания сельскохозяйственного производства в республике является недоразвитость инфраструктуры хранения и переработки сельскохозяйственного сырья. Одностороннее развитие сельскохозяйственного производства без соответствующего развития инфраструктуры перерабатывающей отрасли не может обеспечить конечных целей развития агропромышленного комплекса. Слабое развитие перерабатывающих отраслей агропромышленного комплекса приводит к значительным потерям собранного урожая.

Проблема межотраслевой сбалансированности весьма актуальна, от сбалансированного развития составляющих комплекса зависит общий итог деятельности.

Аграрное производство имеет свою специфику: экономический процесс воспроизводства в сельском хозяйстве тесно переплетается с естественными циклами, а труд имеет сезонный характер и связан с использованием природных ресурсов и живых организмов [23].

Исследуя агропромышленный комплекс как макрологистическую систему, необходимо определить его связи с внешним окружением, изучить характер входных, внутренних и выходных потоков, их сбалансированность во времени и пространстве.

«Внешняя среда АПК - логистической системы - представляет собой триединство социума, рынка и государства, находящихся в органическом единстве взаимодействия и динамическом балансе влияния на все структуры системы АПК» [6].

Большинство авторов выделяет в логистике АПК лишь материальные, финансовые и информационные потоки $[2,6]$. Помимо них для логистической системы АПК важно выделить также природно-ресурсные, институциональные и трудовые потоки.

Параметры входных потоков АПК региона определяются в первую очередь природноресурсной средой, которая относительно системы АПК является первичной.

Природно-ресурсные потоки в логистической системе АПК должны быть совместимыми и соответствовать известным шести правилам логистики, но при этом обеспечивать минимум затрат и ущерба для самой природы.

Понятие «логистический поток» применим, на наш взгляд, и по отношению земельных ресурсов. Размеры площадей сельскохозяйственных угодий, их структура, зонирование и качественные свойства почв в пространстве и во времени образуют дискретный поток земельных ресурсов в логистической системе АПК.

Природно-ресурсные потоки выступают лишь начальным звеном в длинной природнопродуктовой логистической цепи. Можно увеличить входные потоки природных ресурсов с 
целью повышения конечных результатов АПК, но это может привести к ухудшению состояния природы. Так, планируемый рост поголовья овец может нанести непоправимый вред зимним пастбищам Черных земель и Кизлярских пастбищ, где нагрузка на 1 га приходится сегодня 3 условные головы овец на гектар вместо нормы $0,7$.

Востребованной для природно-ресурсной подсистемы АПК является концепция совокупных затрат. Данная основополагающая концепция логистики предусматривает комплексную оценку всех используемых ресурсов, включая природные. На основе имеющихся ресурсов, применяя новые технологии, можно увеличить объем конечной продукции.

Природа Дагестана уникальна своим разнообразием - от субтропических лесов до ледников. Потому и разнообразна здесь выращиваемая продукция растениеводства. Однако малоземелье и резкая пересеченность земельных угодий в горной части республики накладывает определенный отпечаток на развитие этой отрасли. Дагестан имеет всего 359 тыс. гектаров посевных площадей, а это лишь 0,4 процента всей посевной площади РФ, в то время как население республики составляет более двух процентов населения страны. Таким образом, в расчете на одного жителя Дагестана приходится в пять раз меньше посевной площади, чем на одного жителя РФ. А если еще учесть, что в Дагестане численность сельского населения преобладает над городским населением, картина дефицита земли выглядит еще более удручающей.

Для обеспечения продовольственной безопасности стратегическое значение имеет рациональное использование пашни республики. На долю пашни приходится примерно 16 \% сельхозугодий, а это самый низкий показатель в сравнении с другими регионами. За период рыночных реформ площадь пахотных земель в республике сократилась с 505 тыс. га до 462 тыс. га. Из имеющейся пашни не используемыми под посевами остаются 68 тыс. га, или 15 \% пашни, это не считая под пары и плантаж. Три четверти территории республики размещено в острозасушливых условиях, 16 \% - в условиях не обеспеченной осадками богары и лишь $9 \%$ в условиях более или менее достаточного увлажнения. Плодородие почв республики в 2-3 раза ниже по сравнению с другими субъектами СКФО. Содержание гумуса в них не превышает $2,5-3,0 \%$.

В предгорьях и горах 60 \% земель представлены склонами, из которых около 40 \% обладают крутизной более $25 \%$ и подверженностью почв водной и ветровой эрозии.

В структуре посевных площадей основная доля приходится на зерновые культуры $(38,3$ \%). Производство зерна в республике всегда было ключевым направлением в растениеводстве, и за 2010-2016 оно увеличилось на 79 \%. При этом валовой сбор озимой пшеницы увеличился в 2,4 раза, а ее доля в общем объеме валового сбора зерна составила 44 \%.

Самой ценной и перспективной зерновой культурой в наших условиях является рис. Значительные площади засоленных земель в республике могут быть вовлечены в севооборот и продуктивно использованы только путем возделывания риса. За 2010-2016 годы в республике производство риса также увеличилось в 2,4 раза. В 2016 году его валовый сбор составил 76,4 тыс. т, а это 85 \% дореформенного уровня.

Возделывание зерновых культур в горах совершенно убыточно. Поля, которые раньше колосились зерновыми культурами, заросли сорняками. Вместо зерновых отчасти можно было, конечно, выращивать картофель и овощи. Но опять-таки, для этого требуется не только специальная сельхозтехника, приспособленная для горной местности, но и организация инфраструктуры для полива этих горных земель, что, по сути, технически не осуществимо в настоящее время.

И неудивительно, что даже в тех горных районах, где традиционно выращивали картофель, нынче на рынках продают египетскую картошку.

Овощи, выращенные в горах, экологически чистые и имеют свой неповторимый вкус, но себестоимость их производства высока, и они неконкурентоспособны на рынке. Возможно, со временем на рынке появится для такой продукции своего рода ниша.

Природные и климатические условия исторически определили развитие садоводства и виноградарства в Дагестане. Садоводство и виноградарство имеет целевую поддержку со стороны государства.

Республика Дагестан специализируется на производстве плодоовощной продукции. Доля 
продукции растениеводства РД составляет 1,7 \% продукции этой подотрасли страны. Однако значительна доля республики в валовом сборе продукции РФ - винограда $(26,9 \%)$, плодов и ягод (16,7 \%), а также овощей $(8,7 \%)$. Дагестан по производству овощей среди субъектов РФ занимает первое место, по производству винограда - второе место и по производству плодов и ягод - пятое место.

Взаимозаменяемость и взаимодополняемость факторов сельскохозяйственного производства обеспечивают выход конечной продукции при рациональном землепользовании. Улучшение земли, повышение плодородия почв, техническое и технологическое совершенствование агробизнеса увеличит объемы производства.

Для развития АПК региона важное значение имеет не только природно-ресурсная, но и институциональная среда. Институциональная среда обеспечивает наличие и поток институтов неформальных и формальных правил землепользования и организации аграрного производства. На межфирменном уровне институтами логистики выступают хозяйственные договоры, контракты, соглашения, графики поставок и т. д. На уровне региона таковыми выступают стандарты, положения, программы и законы.

Целевые программы, постановления и законы, касающиеся вопросов развития агропромышленного комплекса, должны быть оценены с позиций логистической оптимизации и устранения структурной несбалансированности в системе.

Возникновение, развитие, изменение и замена одних формальных или неформальных правил другими образует институциональный поток. Управление институциональными потоками в логистических системах включает анализ институциональной среды, определение необходимости в новых институтах и их разработка.

Главным институциональным отношением в сельском хозяйстве выступают земельные отношения. Имея в собственности $6 \%$ сельскохозяйственных угодий, хозяйства населения республики производят 80 \% от общего объема продукции. Население и фермеры арендуют землю у сельскохозяйственных организаций. Нерешенность земельного вопроса ограничивает развитие сельскохозяйственного производства.

Рыночные отношения, а, соответственно, и финансовая среда, обуславливают финансовые потоки, которые стимулируют как землепользование, так и функционирование всех других звеньев АПК.

Финансовые потоки в отраслях АПК обеспечиваются за счет доходов от реализации продукции и средств государственной поддержки.

Недостаточная доходность аграриев увеличивает возможность проявления разного рода рисков, расширяет и обостряет проблемы функционирования агропромышленного комплекса, и в особенности его главной отрасли - сельского хозяйства. На убыточность сельскохозяйственного производства влияют следующие факторы: зависимость от природноклиматических условий, высокая себестоимость и материалоемкость продукции, низкая производительность труда. Входные материальные потоки АПК в стоимостном выражении растут из года в год. Так, цены на технику, горюче-смазочные материалы, удобрения и прочие услуги для сельского хозяйства растут быстрее, чем закупочные цены на сельхозпродукцию.

Государственная поддержка аграрного производства - это общемировая практика. Кризис и санкции сократили объемы государственной поддержки агропромышленного комплекса с 2013 года. Однако и имеющиеся скудные финансовые ресурсы используются неэффективно. Весьма актуально применение логистического подхода - определенное количество соответствующего ресурса должно быть в нужном месте в нужное время.

Институциональные и финансовые потоки дают толчок материальным и трудовым входным потокам в агропромышленном комплексе.

Материальные потоки в логистической системе АПК имеют ряд особенностей, на которые, в частности, указывают и Т. М. Ворожейкина, В. Д. Игнатов [4]. Одними из важных особенностей материальных потоков в АПК является то, что в сельском хозяйстве производственные процессы тесно переплетаются с биологическими. Следовательно, материальные потоки в большинстве случаев могут иметь биологическую природу. Основным источником материальных потоков выступает сельскохозяйственное производство.

Говоря об источниках материальных потоков в АПК, следует отметить мелкотоварность 
сельскохозяйственного производства. Так, почти весь валовой сбор плодоовощной продукции республики обеспечивают хозяйства населения. На долю сельскохозяйственных организаций приходится менее трех процентов валового сбора продукции. Мелкотоварность производства продукции серьезно сказывается на развитии логистической инфраструктуры хранения, переработки и распределения продукции. Только лишь на выращивание винограда приходится значительная доля сельскохозяйственных организаций $-43,5$ \%. Это и понятно: устойчивые урожаи винограда возможны лишь при использовании современных технологий, что под силу только крупным организациям.

Таблииа 1

Динамика производства основных сельхозпродуктов в РД, тыс. т

\begin{tabular}{|l|c|c|c|c|}
\hline & 2010 & 2015 & 2016 & $\begin{array}{c}2016 \text { год в \% } \\
\text { к 2010 году }\end{array}$ \\
\hline Зерно (в весе после доработки) & 209,7 & 341,0 & 375,9 & 179,3 \\
\hline Семена масличных культур (в весе после доработки) & 4,0 & 8,6 & 9,8 & 245,0 \\
\hline Картофель & 307,0 & 382,3 & 396,1 & 129,0 \\
\hline Овощи & 948,9 & 1352,0 & 1414,4 & 149,1 \\
\hline Плоды и ягоды & 109,5 & 128,0 & 131,4 & 120,0 \\
\hline Виноград & 127,2 & 147,6 & 148,6 & 116,8 \\
\hline Скот и птица на убой (в убойном весе), тыс. т, & 87,3 & 125,5 & 134,1 & 153,6 \\
\hline в т. ч. птица & 7,8 & 40,3 & 45,7 & 585,9 \\
\hline Молоко, тыс. т & 591,7 & 820,2 & 845,5 & 142,9 \\
\hline Яйца, млн шт. & 211,6 & 230,0 & 241,0 & 113,9 \\
\hline
\end{tabular}

Источник: Составлено по данным Росстата.

Развитие животноводства в Дагестане обусловлено наличием значительных сельскохозяйственных угодий в виде пастбищ - 77 \%. По поголовью овец и коз республика занимает первое место в России. Как видно из таблицы 1, производство скота и птицы на убой за анализируемый период увеличилось в полтора раза, в том числе птицы почти в шесть раз. Таким образом, производство мяса в убойном весе без учета птицы увеличилось лишь на 11,1 \%, что является незначительным за 16 лет. Потребность рынка в мясе собственным производством покрывается на 95 \%. В этом случае анонсируемый вывоз мяса за пределы республики (в Иран или Татарстан) может привести к росту цен на мясо на местных рынках.

Положительная динамика достигнута и в производстве молока (рост 42,9 \%). Однако есть основание критически относиться к такому росту. К примеру, в СКФО за этот период производство молока увеличилось лишь на 18,5 \%. В 2010 году первое место по производству молока в СКФО занимал Ставропольский край - 633,7 тыс. т. За 16 лет производство молока здесь увеличилось лишь на 7,5 \%. Рост производства молока в 1,4 раза в Дагестане, при росте поголовья коров на $16,5 \%$, является, на наш взгляд, «статистическим феноменом».

Хотя по производству мяса птицы имеется существенный рост, этого нельзя сказать о производстве яиц. Собственное производство яиц покрывает меньше половины потребляемого объема этого продукта в республике.

Сельскохозяйственное производство носит сезонный характер, а потребление пищи - процесс постоянный, что требует хранения и переработки сельхозсырья. Отсутствие или недостаточное развитие инфраструктуры заготовки, хранения и переработки приводит к большим потерям сельскохозяйственного сырья. В развивающихся странах эти потери доходят до 20 50 \% объемов производства. Развитие сельскохозяйственного производства должно быть синхронизировано и сбалансировано с развитием перерабатывающей и пищевой промышленности. 
Динамика производства пищевых продуктов в РД за период

\begin{tabular}{|l|c|c|c|c|}
\hline & 2010 & 2015 & 2016 & $\begin{array}{c}2016 \text { год в \% к } \\
2010 \text { году }\end{array}$ \\
\hline Мясо и субпродукты всего, тыс. т & 3,0 & 7,2 & 6,8 & 226,7 \\
\hline Мясо и субпродукты птицы, т & 1852,0 & 2825,5 & 2675,8 & 144,5 \\
\hline Изделия колбасные, т & 958,6 & 1401,2 & 1378,3 & 143,8 \\
\hline Сыр и творог, т & 3373,2 & 5752,7 & 6145,6 & 182,2 \\
\hline Сыры и продукты сырные, т & 2150,0 & 2883,5 & 3282,1 & 152,7 \\
\hline Масло сливочное и пасты масляные, т & 294,6 & 518,8 & 468,4 & 159,0 \\
\hline Йогурт и прочие виды, т & 3681,3 & 5958,6 & 5965,3 & 162,0 \\
\hline Консервы плодоовощные & 32,9 & 25,3 & 38,2 & 116,1 \\
\hline $\begin{array}{l}\text { Цельномолочная продукция } \\
\text { в пересчете на молоко), тыс. т }\end{array}$ & 23,9 & 29,3 & 28,9 & 120,9 \\
\hline Хлеб и хлебобулочные изделия, тыс. т & 207,3 & 209,9 & 209,7 & 101,2 \\
\hline Кондитерские изделия, тыс. т & 10,2 & 18,4 & 18,4 & 180,4 \\
\hline Коньяк, тыс. дкл & 1830,1 & 1254,3 & 1130,3 & 61,8 \\
\hline Вина столовые, тыс. дкл & 361,8 & 238,8 & 291,3 & 80,5 \\
\hline Мороженое, т & 829,1 & 910,0 & 803,7 & 96,9 \\
\hline
\end{tabular}

Источник: составлено по данным Росстата.

Как видно из таблицы 2, за анализируемый период производство многих пищевых продуктов развивается быстрее, чем их сельскохозяйственное сырье (см. таблицу 1). Однако если учесть, что перерабатывается менее одной десятой части сельхозсырья, то темпы роста развития переработки крайне недостаточны. В первую очередь отстающим звеном в системе выступает переработка плодоовощной продукции.

Промышленное консервирование плодоовощной продукции берет развитие в Дагестане с конца 80-х годов XIX века. В 1903 году в Темир-Хан-Шуре и округе насчитывалось 45 консервных предприятий, в том числе 9 крупных. В 30-х годах XIX века были построены крупные консервные заводы в городах Буйнакск, Дербент, Хасавюрт и Махачкала, заложив тем самим основы данной индустрии. В результате чего в 1940 году объем производства плодоовощных консервов достиг 32 муб, а это в 2,7 раза больше, чем в 1916 году. Пик производства плодоовощных консервов приходится на начало 1990-х годов, когда было произведено 350 муб (2-е место в России) и переработано более 110 тыс. т сельхозсырья.

Однако с развалом СССР развалилась и вся перерабатывающая промышленность Дагестана. Об этом свидетельствую данные таблицы 3.

Таблииа 3

Динамика развития производства и переработки плодоовощной продукции в РД

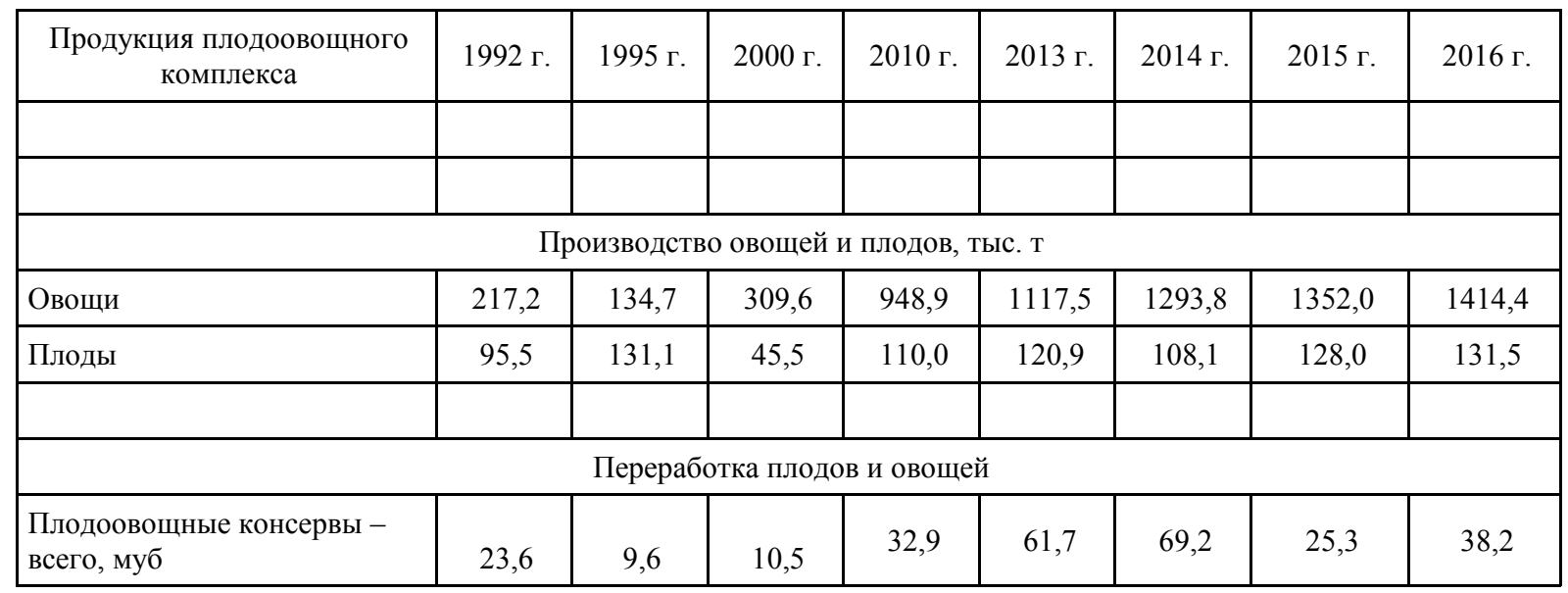

Источник: составлено по данным Росстата. 
Как видно из таблицы 3 , наименьшее количество плодоовощной продукции было произведено и переработано в 1995 году, а с 2000 года происходит некоторое оживление в данной сфере. В 2014 году был достигнут максимум в производстве плодоовощных консервов - 69,2 муб, но это лишь пятая часть дореформенного уровня.

В литературе отмечается, что «...процесс реформирования собственности перерабатывающих предприятий АПК в Республике Дагестан фактически не решил одну из главных задач установление равноправных отношений сельскохозяйственных предприятий со сферой переработки» [5].

Но нельзя согласиться и с мнением, что консервные заводы стали меньше перерабатывать продукцию от того, что они «оказались в частной собственности» [8]. При плановом хозяйстве объемы производства определялись планом, а в условиях рынка не производится то, что не пользуется спросом. А спрос изменился. Монопольное положение переработчиков относительно закупки сельхозсырья не сохранило монопольного положения на рынке готовой продукции. На рынок хлынули из зарубежья продукты, изготовленные на более высокой технологической основе. Перерабатывающей промышленности потребовались крупные инвестиции для технической модернизации.

В 2016 году на 11 предприятиях было переработано лишь 8,3 тыс. тонн плодов и 2,9 тыс. тонн овощей и выпущено 38,2 муб различной плодоовощной консервной продукции. Было переработано лишь 8,3 \% собранного урожая плодов и $0,2 \%$ овощей.

Ситуация с потреблением плодоовощных консервов в республике лишь повторяет ситуацию в стране. Среднедушевое потребление консервов в России составляет 24 усл. банки при биологической норме потребления 104 усл. банки.

При планировании производства и сбыта продукции на перерабатывающих предприятиях АПК в современных условиях хозяйствования следует выделить стратегическое и тактическое в их ассортиментной политике [13]. В структуре выпускаемой продукции $80 \%$ составляют соки и $15 \%$ различные овощные консервы. Ассортимент продукции консервных заводов страны ограничен, выпускается лишь не более 100 видов из 1000 наименований [18].

Основная мощность действующих предприятий (всего 13 заводов) приходится на заводы средней мощности. Но в 2016 году производственная мощность консервных предприятий была использована лишь на 8 \%. Недействующие предприятия (17 заводов), за исключением Хасавюртовского консервного завода, - это груда металлолома. Но из действующих предприятий только три являются современными: ООО «Кикунинский консервный завод», ООО «Азерконсерв» и ООО «Дагагрохолдинг».

Опыт Хасавюртовского и Кикунинского заводов подтверждает, что предприятия самостоятельно не в состоянии провести техническую модернизацию без кредитной подпитки, но эта подпитка часто становится финансовой удавкой для самих предприятий. К сожалению, это сегодняшние реалии финансового ростовщичества, которые душат развитие бизнеса.

Материально-техническая база многих предприятий консервной промышленности остается на уровне 80-х годов прошлого века, которая в основном состоит из морально устаревшего, малопроизводительного и физически изношенного оборудования. Темпы обновления основных фондов не отвечают задачам развития отрасли. На устаревшем оборудовании предприятия не в состоянии обеспечить внедрение современных безотходных технологий и производство высококачественной конкурентоспособной продукции. Из-за слабой технической оснащенности 40 \% трудоемких операций выполняется вручную, повышается себестоимость продукции и снижается ее рентабельность. Сложилась ситуация, когда требуется масштабная замена производственных мощностей, ведь, по оценкам специалистов, 85 \% основных фондов отрасли республики изношено [7].

Ситуация, присущая материально-технической базе консервной промышленности Дагестана, не является специфичной только для данной республики. Многие специалисты из регионов отмечают, что недостаточная материально-техническая база предприятий перерабатывающей промышленности и неразвитая логистическая инфраструктура заготовки, хранения, перевозки скоропортящегося сырья и продовольствия не позволяют комплексно перерабатывать исходное сырье и создавать необходимые условия для хранения, что приводит к дополнительным потерям на пути к конечному потребителю. 
Для перерабатывающих предприятий проблемой остается приобретение сырья, поскольку практически весь объем плодов и овощей в республике производится в частном секторе, вследствие чего имеются сложности в заключении предварительных договоров между заводами и сельскохозяйственными производителями о поставках сырья в сезон переработки. При этом отсутствие у перерабатывающих предприятий оборотных средств не способствует тому, чтобы сельское население проявляло заинтересованность в выращивании продукции в больших объемах.

Кроме того, в структуре выращиваемых в республике овощей значительное место занимает капуста, около 600 тыс. тонн, которая практически не перерабатывается консервными предприятиями РД.

Три четверти произведенной консервными предприятиями продукции реализуется на рынках республики, а остальное вывозится в другие регионы РФ. Однако на долю местных плодоовощных консервов приходится лишь 10 \% всего потребления консервов в республике [7].

Логистика требует и рационального размещения предприятий на территории. Анализ размещения перерабатывающих предприятий в районах выращивания плодов и овощей республики показывает, что действующие мощности консервной промышленности вовсе отсутствуют в десяти районах, где возделываются сады.

Больше всего плодоносящих садов имеется в Магарамкентском районе - 3760 га, но в районе не работает ни одно перерабатывающее предприятие. Второе место по площадям плодоносящих садов занимает Сулейман - Стальский район. В районе только начато строительство завода по производству концентрата сока из фруктов и винограда.

Левашинский, Хасавюртовский и Дербенсткий районы выращивают более полумиллиона тонн овощей в год. Но и в них проблема переработки овощей стоит остро, как и во всей республике.

Для выхода консервной промышленности из системного кризиса, в целях улучшения экономической и финансовой ситуации в отрасли, кроме решения проблемы технической и технологической отсталости, увеличения количества и повышения качества выпускаемой консервной продукции, главной и первоочередной задачей является активизация инновационной и инвестиционной деятельности, строительство новых предприятий.

Однако в России наметилась та тенденция, когда «многие компании отказываются от строительства заводов, потому как в некоторых случаях выгоднее реконструировать существующие на рынке мощности. Следующий шаг - развитие собственной сырьевой базы, а затем производители, работающие в дешевом сегменте консервного рынка, постепенно осваивают «премиум-сегмент» [17].

В целом по стране основными поставщиками плодоовощной продукции для перерабатывающих предприятий выступают сельскохозяйственные организации. И многие сельскохозяйственные организации, так или иначе, интегрированы в крупные компании, куда включены и перерабатывающие предприятия. «При этом следует отметить, что степень интеграции различна - от «мягкой», когда сельхозпроизводитель производит и поставляет продукцию на переработку по контракту, сохраняя юридическую и экономическую независимость, до «жесткой», при вхождении сельхозпредприятия в структуру интегрированной компании [3].

Кардинально отличается ситуация в Республике Дагестан, где основными производителями плодоовощной продукции выступают хозяйства населения. Для крупной консервной индустрии в республике нет сырьевой базы. Предприятия, желающие иметь такую сырьевую базу в виде собственных площадей под сады и овощи, встречаются с различными институциональными препонами. И главная проблема - это земля, которая еще не приватизирована, но под видом долгосрочной аренды «прихвачена» различными коммерческими структурами. Консервные заводы, а они в основном ООО (т. е. в случае чего не отвечают за что-либо), желают приобрести выращенный урожай у населения с рассрочкой платежа. Однако у хозяйств населения нет доверия в условиях неустойчивого развития. Между сельхозпроизводителями и консервщиками необходима сельскохозяйственная потребительская кооперация. А развитию такой сельскохозяйственной потребительской кооперации требуется постоянная государственная поддержка.

Развитие сельского хозяйства зависит от уровня промышленной переработки сельскохозяй- 
ственного сырья. Во многих районах практически нет производственной и логистической инфраструктуры. Получается замкнутый круг: нет товарного производства сельхозпродукции нет и его промышленной переработки, нет промышленной переработки - нет и стимулов для развития сельского хозяйства.

Аграрная сфера и промышленная переработка сельхозсырья, используя преимущества разделения труда, могут до определенной степени развиваться вполне независимо друг от друга, и даже эффективно. Но на определенном этапе возникает необходимость в логистической интеграции всех подсистем АПК.

На межфирменном уровне агропромышленного комплекса сельхозпроизводители и предприятия перерабатывающей промышленности устанавливают между собой взаимовыгодные интеграционные связи с последующим образованием логистической цепи. Рыночный механизм способствует формированию логистической системы агропромышленного комплекса. Однако этот процесс долгий, и в условиях международной конкуренции - болезненный. Политика импортозамещения сулила большие выгоды в этом плане, но ожидания оказались преувеличенными. Мы не сможем полностью закрывать границы для ввоза в страну продуктов питания и тем самым стимулировать развитие отечественного производства. Но и на старых мощностях не в состоянии выпускать современную конкурентоспособную продукцию.

Стратегия, определяемая интегральной логистической концепцией, должна минимизировать проблемы, конфликты, обеспечивать диспаритет во взаимоотношениях и способствовать получению синергического эффекта от взаимодействия, «согласованного сотрудничества во всей логистической цепочке в агропромышленном комплексе» [14].

Процесс интеграции структур агропромышленного комплекса выступает одним из важных направлений в деле расширения деятельности сельскохозяйственных организаций и, соответственно, перерабатывающей промышленности [19].

Государство всесторонне должно поддерживать развитие логистической интеграции в агропромышленном комплексе по технологической цепи «производство сырья - переработка реализация», и в первую очередь развивая производственную и потребительскую кооперацию.

Государственная аграрная политика должна инициировать образование логистических цепей «поле (ферма) - переработка - прилавок». На уровне региона востребованными являются механизмы государственного регулирования по сбалансированному использованию ограниченных природных ресурсов и социально-экономического развития территорий. Лишь применение интегрированных логистических цепей «производство - хранение - переработка - перевозка - реализация - потребление» в агропромышленном комплексе изменит ситуацию.

Логистическая интеграция всех участников агропромышленного комплекса по технологической цепочке (от фермы и поля до потребителя) призвана формировать условия для непрерывного поддержания межотраслевых пропорций, структуры и объемов производства, продовольственного баланса с учетом соблюдения интересов всех участников. Каждая из форм интеграции обладает преимуществами и недостатками. В каждом конкретном случае интеграционные связи должны быть спроецированы с учетом региональных особенностей и прогнозируемого синергетического эффекта от взаимодействия участников цепи [21].

Интеграция сельскохозяйственного производства, пищевой и перерабатывающей промышлености и сбыта продукции должна обеспечить формирование кластеров в АПК региона. Решение указанных вопросов возможно при комплексном взаимодействии системы управления, научных достижений и финансовых потоков и использовании кластерных подходов [1].

К основным факторам, сдерживающим развитие сельскохозяйственной кооперации, относятся: недостаточно развитая производственная инфраструктура, нехватка баз хранения овощеперерабатывающих предприятий, подъездных путей к местам массового производства овощной продукции малыми формами хозяйствования. Решить эти проблемы фермерам без объединения усилий и государственной помощи не под силу [16].

Выводы. Деятельность агропромышленного комплекса во многом определяется природноклиматическими условиями и носит сезонный характер. Сельскохозяйственное производство влияет на уровень социально-экономического развития региона, от качества продовольствия зависит здоровье населения, а технологии возделывания и переработки сельхозпродукции влияют на окружающую среду. 
Агропромышленный комплекс состоит из различных подсистем, которые имеют между собой взаимосвязи, образуя макрологистическую систему. Целью данной логистической системы является максимальное удовлетворение потребностей в продукции таких секторов экономики, как домашние хозяйства и предприятия.

Проведенный анализ деятельности АПК Дагестана говорит о существующих диспропорциях в развитии отдельных подсистем, структурной несбалансированности производства, заготовки, переработки, хранения, транспортировки, складирования и реализации сельхозпродукции.

Логистическая интеграция в агропромышленном комплексе должна обеспечить наличие в установленное время в определенных местах заданного количества природно-ресурсных, материальных, институциональных, трудовых финансовых и информационных потоков соответствующего качества.

Логистическая интеграция подсистем АПК требует государственной (в том числе и на уровне региона) политики в области разработки отраслевых стандартов, положений, технических условий производства, поставок, транспортировки и хранения продукции, порядка выбора приоритетных проектов и целевых программ развития, механизмов государственной поддержки АПК [11].

\section{Литература}

1. Айгумов А. Дж., Магомедова М. М. Особенности создания кластерных формирований в депрессивных регионах // Экономика и предпринимательство. - 2015. - № 12-2 (65-2). - C. 311-316.

2. Бейбалаева Д. К., Амирханова А. Ш. Тенденции развития логистики аграрнопромышленного комплекса Республики Дагестан // Региональные проблемы преобразования экономики. - 2012. - № 2. - С. 229 235.

3. Богачев Д. В. Основные особенности развития вертикально интегрированных компаний в агропромылиленном комплексе России // Региональные исследования. - 2015. - № 1 (47). - C. 52-62.

4. Ворожейкина Т. М., Игнатов В. Д. Логистика в АПК. - М.: Колосс, 2007. - 184 с.

5. Гитиномагомедова Х. М. Агропромышленная интеграция как фактор повышения эффективности в отраслях перерабатывающего подкомплекса АПК региона (на примере Республики Дагестан) // Вестник Дагестанского государственного университета. Серия 3: Общественные науки. - 2009. - № 5. - С. 69-75.

6. Гончаров П. П., Едаков А. Е. Развитие логистики на предприятиях АПК // Известия Оренбургского государственного аграрного университета. - 2012. - T. 33. - № 1-1. - С. 195-198.

7. Имашова Д. Г., Имашов С.Н. Особенности развития перерабатывающей промышленности // Вопросы структуризации экономики. 2013. - № 4. - С. 258-261.

8. Казиев М. Р. А. Концепџия развития сельского хозяйства в Республике Дагестан // Горное сельское хозяйство. - 2016. - № 3. - С. 24-30.

9. Казиханов А. М., Гаджиев Н. Г. Импортозамещение как условие повышения продовольственной безопасности // Вестник Дагестанского государственного университета. Серия 3: Общественнье науки. - 2016. - № 4. - С. 6-11.

10. Кокунова И. В. Особенности использования логистического подхода в агропромышленном комплексе // Известия Великолукской государственной сельскохозяйственной академии. - 2015. - № 3. - С. 37 45.

11. Магомедов А. М. Институты и институцииональные потоки логистической системы // Управление экономическими системами: электронный научный журнал. - 2013. - № 5 (53). - С. 18.

12. Магомедов А. М. Природопользование региона на основе логистики (на примере Республики Дагестан) // Региональная экономика: теория и практика. - 2013. - № 17. - C. 20-26.

13. Магомедова М. М., Камбарова С. Р. Методические подходы к планированию производства и сбыта продукции на перерабатывающих предприятиях АПК // Региональные проблемы преобразования экономики. - 2015. - № 12 (62). - С. 75-84.

14. Меделяева 3. П., Ляшко С. М., Голикова С. А. Взаимозависимость сельхозтоваропроизводителей и предприятий пищевой промышленности в логистической системе АПК // Вестник Воронежского государственного аграрного университета. - 2017. - № 1. - С. 175-181.

15. Смирнов И. Г., Шматок О. В. Агрологистика в Украине: современное состояние, проблемы и перспективы развития // Псковский регионологический журнал. - 2014. - № 18. - C. 15-27.

16. Ткач А. В., Черевко А. В. Стратегия развития овощъного подкомплекса Краснодарского края на основе кооперации // Экономика сельского хозяйства России. - 2014. - № 2. - C. 49-57.

17. Томилина Е. П., Глотова И. И. Формирование интеграционных связей предпринимательских структур - основное условие развития отрасли садоводства // Вестник АПК Ставрополья. - 2011. - № 3 (3). - C. 121-123.

18. Третьяков Н. А. Современное состояние и возможное направление развития плодоовощной перерабатывающей промышленности // Научный журнал НИУ ИТМО. Серия: Процессы и аппараты пищевых производств. - 2015. - № 1. - C. 167-172. 
19. Фролова О. А., Кулькова Н. С. Проблемы и перспективы развития интегрированных структур в АПК // Вектор науки Тольяттинского государственного университета. Серия: Экономика и управление. - 2015. - № 1 (20). - C. 47-50.

20. Чулкова Г. В., Лакеев С. В. Проблемы современного развития логистики в АПК // Вестник Мичуринского государственного аграрного университета. - 2015. - № 4. - С. 111-116.

21. Ялунина Е. Н., Гаянова В. М. Организационно-экономические вопросы развития агропромышленной интеграции // Экономика сельского хозяйства России. - 2014. - № 12. - C. 56-62.

22. D. Vaněček, D. Kaláb (2003): Logistics in agricultural production. Agric. Econ. Czech, 49: 439-443.

23. Molchan A. S., Frantsisko O. Yu., Ternavshchenko K. O., Illarionova V. V., Prokhorova V. V. (2017) Organizational Structure of Agro-Industrial Complex: Formation and Interaction of Subjects. International Journal of Applied Business and Economic Research. T. 15. No. 23. P. 281-296.

\section{References:}

1. Ajgumov A. Dzh., Magomedova M. M. Osobennosti sozdaniya klasternyh formirovanij v depressivnyh regionah // EHkonomika i predprinimatel'stvo. 2015. No. 12-2 (65-2). S. 311-316.

2. Kokunova I. V. Osobennosti ispol'zovaniya logisticheskogo podhoda v agropromyshlennom komplekse // Izvestiya Velikolukskoj gosudarstvennoj sel'skohozyajstvennoj akademii. 2015. No. 3. S. 37-45.

3. Magomedov A. M. Instituty i institucional'nye potoki logisticheskoj sistemy // Upravlenie ehkonomicheskimi sistemami: ehlektronnyj nauchnyj zhurnal. 2013. No. 5 (53). S. 18.

4. Magomedov A. M. Prirodopol'zovanie regiona na osnove logistiki (na primere Respubliki Dagestan) // Regional'naya ehkonomika: teoriya i praktika. 2013. No. 17. S. 20-26.

5. Magomedova M. M., Kambarova S. R. Metodicheskie podhody k planirovaniyu proizvodstva i sbyta produkcii na pererabatyvayushchih predpriyatiyah APK // Regional'nye problemy preobrazovaniya ehkonomiki. 2015. No. 12 (62). S. 75-84.

6. Medelyaeva Z. P., Lyashko S. M., Golikova S. A. Vzaimozavisimost' sel'hoztovaroproizvoditelej i predpriyatij pishchevoj promyshlennosti v logisticheskoj sisteme APK // Vestnik Voronezhskogo gosudarstvennogo agrarnogo universiteta. 2017. No. 1. S. 175-181.

7. Smirnov I. G., Shmatok O. V. Agrologistika v Ukraine: sovremennoe sostoyanie, problemy i perspektivy razvitiya // Pskovskij regionologicheskij zhurnal. 2014. No. 18. S. 15-27.

8. Tkach A. V., Cherevko A. V. Strategiya razvitiya ovoshchnogo podkompleksa krasnodarskogo kraya na osnove kooperacii // Ehkonomika sel'skogo hozyajstva Rossii. 2014. No. 2. S. 49-57.

9. Tomilina E. P., Glotova I. I. Formirovanie integracionnyh svyazej predprinimatel'skih struktur - osnovnoe uslovie razvitiya otrasli sadovodstva // Vestnik APK Stavropol'ya. 2011. No. 3 (3). S. 121-123.

10. Tret'yakov N. A. Sovremennoe sostoyanie $i$ vozmozhnoe napravlenie razvitiya plodoovoshchnoj pererabatyvayushchej promyshlennosti // Nauchnyj zhurnal NIU ITMO. Seriya: Processy $i$ apparaty pishchevyh proizvodstv. 2015. No. 1. S. 167-172.

11. Frolova O. A., Kul'kova N. S. Problemy i perspektivy razvitiya integrirovannyh struktur v APK // Vektor nauki Tol'yattinskogo gosudarstvennogo universiteta. Seriya: EHkonomika i upravlenie. 2015. No. 1 (20). S. 47 -50 .

12. Bejbalaeva D. K., Amirhanova A. SH. Tendencii razvitiya logistiki agrarnopromyshlennogo kompleksa Respubliki Dagestan // Regional'nye problemy preobrazovaniya ehkonomiki. 2012. No. 2. S. 229-235.

13. CHulkova G. V., Lakeev S. V. Problemy sovremennogo razvitiya logistiki v APK // Vestnik Michurinskogo gosudarstvennogo agrarnogo universiteta. 2015. No. 4. S. 111-116.

14. Yalunina E. N., Gayanova V. M. Organizacionno-ehkonomicheskie voprosy razvitiya agropromyshlennoj integracii // EHkonomika sel'skogo hozyajstva Rossii. 2014. No. 12. S. 56-62.

15. D. Vaněček, D. Kaláb (2003): Logistics in agricultural production. Agric. Econ. Czech, 49: 439-443.

16. Molchan A. S., Frantsisko O. Yu., Ternavshchenko K. O., Illarionova V. V., Prokhorova V. V. (2017) Organizational Structure of Agro-Industrial Complex: Formation and Interaction of Subjects. International Journal of Applied Business and Economic Research. T. 15. No. 23. S. 281-296

17. Bogachev D. V. Osnovnye osobennosti razvitiya vertikal'no integrirovannyh kompanij v agropromyshlennom komplekse Rossii // Regional'nye issledovaniya. 2015. No. 1 (47). S. 52-62.

18. Vorozhejkina T. M., Ignatov V. D. Logistika v APK. M.: Koloss, 2007. 184 s.

19. Gitinomagomedova H. M. Agropromyshlennaya integraciya kak faktor povysheniya ehffektivnosti $v$ otraslyah pererabatyvayushchego podkompleksa APK regiona (na primere Respubliki Dagestan) // Vestnik Dagestanskogo gosudarstvennogo universiteta. Seriya 3: Obshchestvennye nauki. 2009. No. 5. S. 69-75.

20. Goncharov P. P., Edakov A. E. Razvitie logistiki na predpriyatiyah APK // Izvestiya Orenburgskogo gosudarstvennogo agrarnogo universiteta. 2012. T. 33. No. 1-1. S. 195-198.

21. Imashova D. G., Imashov S. N. Osobennosti razvitiya pererabatyvayushchej promyshlennosti // Voprosy strukturizacii ehkonomiki. 2013. No. 4. S. 258-261.

22. Kaziev M. R. A. Koncepciya razvitiya sel'skogo hozyajstva v Respublike Dagestan // Gornoe sel'skoe hozyajstvo. 2016. No. 3. S. 24-30.

23. Kazihanov A. M., Gadzhiev N. G. Importozameshchenie kak uslovie povysheniya prodovol'stvennoj bezopasnosti // Vestnik Dagestanskogo gosudarstvennogo universiteta. Seriya 3: Obshchestvennye nauki. 2016. No. 4. S. 6-11. 